\title{
Flexible Forms of Contracts: Transactions through Fictitious Settlements (șulḥ/muṣālaḥa) in Iran
}

\author{
Christoph U. Werner \\ University of Bamberg, Bamberg, Germany \\ christoph.werner@uni-bamberg.de
}

\begin{abstract}
In the second half of the nineteenth century, practitioners of law in Iran were looking for more flexibility in contractual forms, especially those used to conclude routine transactions of properties and services. They increasingly made use of a type of contract named mușālaḥa-nāma, derived from the legal concept of șulh and defined primarily as a means to arrange the amicable settlement of disputes. The present contribution attempts to categorise the kind of transactions for which this universal contractual type could be employed and raises the question what advantages such a "new" contractual form might have entailed.
\end{abstract}

\section{Keywords}

Qajar Iran - settlement \& composition - Islamic Shiite law - contracts - mușālaḥa

\section{Introduction}

Manuals and handbooks of law can provide a first impression of legal practice and convey an idea of preferred forms of legal transactions and documentation at a certain time and in a certain region. When such information on legal practice enters the domain of language training, this impression is enhanced further. For students of Persian at the beginning of the twentieth century who wanted to leave the narrow confines of classical grammar and literature and were interested in aspects of trade, commerce and law, the range of material at their disposal was limited. One of the few textbooks written with the explicit aim of teaching applied knowledge of 'modern' Persian to a German 
audience was Sebastian Beck's Konversationsgrammatik (1914-15). The author, writing on the eve of World War I, deemed at least a passive command of the scripts Nasta'i $\bar{q}$ and Shikasta to be necessary, and for the advanced student he included a number of exemplary models of decrees, contracts and deeds. The main volume of Beck's grammar introduced these examples in handwritten Shikasta while a separate key to the grammar offered translations and basic expressions in transliteration. ${ }^{1}$

The author, Sebastian Beck, emphasises the authenticity and up-to-date standard of the sample documents of Islamic law taken from a manual entitled Sayyid al-inshä-i naw-zuhür, widely used and distributed in Iran in the second half of the nineteenth century and beyond. ${ }^{2}$ Looking at the documents included and taken verbatim from this work of $i n s h \bar{a}^{3}$ which Beck placed under the heading Legal documents needed by the public, ${ }^{3}$ we see that immediately after the sample of a marriage contract ('aqd-näma) and a letter of attorney (wikālat-nämcha), he introduced a standard civil law contract: Șürat-i qabāla-nämcha-yi shar'ī, which can be roughly translated as Formulary for a standard deed according to sharia law. ${ }^{4}$

Qabāla is a generic term that simply means any kind of written contract, and Beck's translation of the term thus emphasises the actual contents of the deed, calling it a "Grundstücksvertrag" or a contract of landed property. In reality, this sample document is composed in the form of a mușälaha-nāma, a contract of settlement or composition, whereby in this specific case the ownership over a specified garden is transferred to another, unnamed party for a certain sum. The further context of other sample transactions provided by Beck-a deed of conditional sale (bay'-i shart $)^{5}$ a testament (wașiyat-nämcha) or the request for a fatwa (istiftā-nāma) indicates that the qabāla (or rather the muṣa $a$ aḥa) is introduced as a typical example for documenting a simple sale. Beck's Persian

1 S. Beck, Neupersische Konversations-Grammatik (Heidelberg: Groos, 1914): 441-70. S. Beck, Schlüssel zur Neupersischen Konversations-Grammatik (Heidelberg: Groos, 1915): 262-312. See the appendix for an edition and full translation of this sample document.

2 'A.M. Shīrāzī Ḥamzawī, Sayyid al-inshāà-i naw-zuhūr (lithograph Bombay: Faiż-rasān, 1327q/1909). The work has been attributed to Mīrzā Muḥammad Mahdī Khān Astarābādī as the original author, with $12739(1856-57)$ as date of composition. Multiple lithograph prints of this work exist, many from Tehran, see the catalogue entries of the National Library and Archives of I.R. Iran and of the Parliamentary Library of Iran. This collection, its distribution, variants and print history would deserve an independent study.

3 Niwishtajāt-i shar'i ki muhtāj ilayh 'ämma ast. The idea that the public depends on certain legal documents and formularies is interesting in itself.

4 Beck, Neupersische Konversations-Grammatik: 461. Beck, Schlüssel: 293-294.

5 See the contribution by Nobuaki Kondo in the present collection. The mușālaḥa and the bay' $i$ shart are probably the two most characteristic document types of late Qājār Shiite law. 


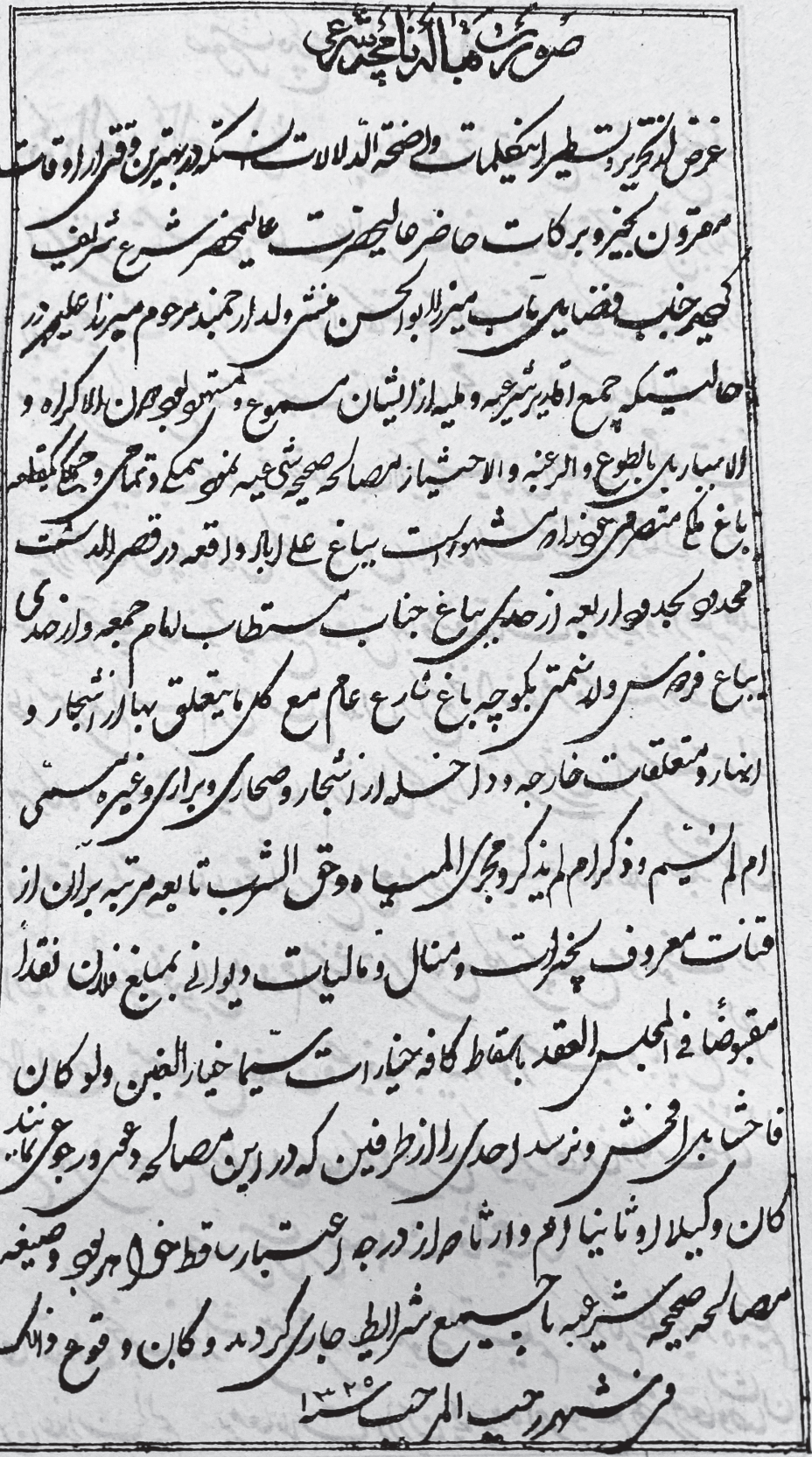

FIGURE 1 Formulary for a standard deed according to sharia law (1914) 
textbook, with its choice of select legal formularies, is an excellent indicator of the type of texts considered representative in Iran at that time.

The question arises why a late nineteenth- / early twentieth-century manual of legal writing from Iran-considered so characteristic that it found its way into a German textbook of modern Persian - does not use an ordinary contract of sale (i.e. a mubāyaca) as a model contract? Furthermore, why does this specific form of contract (i.e the muṣälaha) appear so frequently in nineteenth-century Persian legal usage, becoming the typical standard deed for transactions ( qabāla) in Iran?

This paper traces the rise of the muṣallaha to become the most frequently used contractual form in Iranian legal practice in nineteenth-century Iran and suggests several possible reasons for this development. It also addresses a number of questions that go beyond the immediate issue of legal formularies. ${ }^{6}$ In how far did changes and developments in the judicial system and judicial practice influence the choice of certain contractual forms? How flexible was Shiite law to accommodate social needs by a growing and more diverse society? Is the muṣālaha-contract a primarily Shiite-Iranian phenomenon or if not, how does it translate into the wider Persianate legal sphere?

Before delving deeper into the main subject of this article, contracts of settlement or mușālaḥa-nāmas, some general background on civic legal transactions in Iran, in particular for the later Qājār period from the mid-nineteenth century up to the 1920s, may be helpful. Most of the historical documentation on civil transactions at our disposal, which is to say transactions between private individuals or parties and thus excluding transactions involving taxes, salaries or grants by state or governmental authorities, deals with either agricultural land (including water rights) or real estate. ${ }^{7}$ In the Iranian case, it has been difficult to look closer into commercial transactions related to merchants and

6 For a previous, short discussion of these issues in the context of Qājār sale contracts, see C. Werner, "Formal Aspects of Qajar Deeds of Sale." In Persian Documents, ed. N. Kondo (London: Routledge, 2003): 42-3.

7 Quite representative in this regard are the document collections edited by Hashem Rajabzadeh since 1997 in his Persian Documents Series, the latest devoted to irrigation: H. Rajabzadeh, Eighty-Eight Documents on Irrigation from Qajar Iran (Tokyo: Research and Information Center for Asian Studies, 2019). A monumental older series in eight volumes that includes a large number of mușālaḥa-nāmas in volume 7 is M. Sutūda (ed.), Az Āstārā tā Istārbād (Tihrān: Intishārāt-i Anjuman-i Āṣār-i Millī, 8 vols., 135osh/1971 to 1355sh/1976). 
goods such as textiles, food commodities, currencies etc. without recourse to the registers and balance sheets of western trading houses or consular files. ${ }^{8}$

In short, while transactions involving the physical bazaar proper with its shops, khans and caravanserais were the object of formalised legal documentation, objects traded inside the bazaar often did not involve notaries, judges and scribes, as far as they dispensed formularies of Islamic Shiite law. Reasons for this are manifold; some have to do with the organisation of legal practice in Iran, some with the special situation of merchants and their internal methods of bookkeeping, some with limited access to private collections and some as well with a lack of interest in the field of historical research. ${ }^{9}$

With few exceptions, Iranian civil law followed the ordinances and prescriptions of Shiite jurisprudence which differ in its formularies and contractual types from those employed in Sunni, mainly Hanafì legal systems in other parts of the Persianate world. In other words, Persian as a legal language is secondary to the legal standards, expressed and discussed in Arabic, of the respective law schools and works of jurisprudence. The large percentage of Arabic legal expressions and phrases, sometimes misspelled and not always fully understood by the scribes, is a living testimony to this dominance.

The institutional side of judicial practice in Iran is also of utmost importance. Following the demise of Safavid rule and the emergence of the ușüli legal school in the eighteenth century, the separation of state authority and judicial practice became ever more pronounced. Appointments to the position of judge ( $q \bar{a} \dot{z} \bar{l})$ or imām-jum'a ('leader of the Friday prayer', i.e. leading cleric of a town) still occurred in the Qajjār period, but became increasingly symbolic and nominal. The practice of civil law, including both notarial tasks and the solution of disputes, was in the hands of independent Shiite jurisprudents, mujtahids, who practised law in their largely independent and individual courts. Shiite scholarly hierarchies controlled, and certified the new judicial system by evaluating the individual mujtahid's prestige and reputation. In this way, diverging decisions and rulings could be evaluated and balanced. ${ }^{10}$ This becomes most obvious in the amalgamation of judicial verdicts (ahkām) and judicial opinions $($ fatāwa $)$ — which explains why the legal handbook quoted

8 An exception are the documents from the merchant and entrepreneur Haajj M. Ḥasan Amīn al-Żarb (1837-98), edited in several volumes, as an example A. Mahdawī and İ. Afshār, ed., Yazd dar asnād-i Aminn al-Żarb (Tihrān: Țalāya, 138osh/2001).

9 Representative is the work by Gad Gilbar, an example, with further literature, G. Gilbar, "The Rise and Fall of the Tujjār Councils of Representatives in Iran, 1884-85." Journal of the Economic and Social History of the Orient 51/4 (2008): 639-74.

10 Z. Bhalloo, "Judging the Judge: Judicial Competence in 19th Century Iran." Bulletin d'études orientales 63 (2014): 275-93. 
above introduces the correct form of asking for a legal opinion (istiftā-nāma) as one of the most important legal documents. ${ }^{11}$

When I began research on the social history of Iran in the early nineteenth century, now some two decades ago, and was searching for documents in the archives of a research institute in Tehran, I formulated my request for decrees and deeds from a certain period and region. So you are also interested in mușālaḥa-nāmas, I was asked by the archivist, and —at that time-not knowing exactly what he meant by the term, I nodded and received a couple of deeds of sale on land and real-estate. A cursory glance in the dictionaries showed that muṣālaḥa meant an amicable settlement of disputes, but could be also used more colloquially with the simple meaning of transfer of ownership. For the moment, this seemed sufficient information. However, I soon realised that the number of documents from the sharia courts recorded in the legal form of a mușālaha increased markedly in the second half of the nineteenth century. In fact, many transactions formerly recorded with distinct formularies as sale (bay) or rent/lease (ijära), or donation (hiba), were now written down as muṣālaḥa-nāmas. The verbal noun (mașdar) muṣālaḥa, derived from șălaha, is used to denote the legal contractual form of 'composition' or 'settlement' (șulh) in analogy to mubāya'a (sale) or mu'āważa (exchange). The legal concept of șulh denotes in its basic literary meaning 'peace', and in a more legal terminology it carries the meaning of 'composition', which is to say a mutual agreement or paying off a debt or an obligation. Surprisingly, few of the muṣālaḥa-nāmas I studied at that time mentioned a preceding conflict, dispute, obligation or debt, neither explicitly nor implied.

Traditionally, the legal concept of șulh as a peaceful agreement is based on a number of Koranic passages that laud amicable settlements as commendable, as well as on a number of hadiths. ${ }^{12}$ Among the best known hadiths is the one ascribed to the caliph 'Umar as transmitter in Sunni collections: "The proof is upon the plaintiff, the oath upon the defendant, and a peaceful settlement

11 C. Werner, What is a Mujtahid? Functions and Stratification of Tabrizi 'Ulama in the Early Qajar Period. (Islamic Area Studies, Working Paper Series 19, Tokyo 200o). Most recent and comprehensive N. Kondo, Islamic Law and Society in Iran: A Social History of Qajar Tehran (London: Routledge, 2017).

12 On Koranic references and șuḷ as compared to the judicial concepts of qad̄a (adjudication) and tahkim (arbitration), A. Othman, "'And Amicable Settlement Is Best": Șulh and Dispute Resolution in Islamic Law." Arab Law Quarterly 21/1 (2007): 64-99. 
between Muslims is permissible, unless a settlement allows something forbidden or forbids something which is allowed."13 In this regard, the principal purpose of șulh is to end disputes among Muslims, and in a wider context also to end armed conflicts and war between Muslims and non-Muslims. ${ }^{14}$

In a Sunni, particularly Hanafi context, the aspect of arbitration or mediation therefore dominates the use of șulh in courts, and to provide mechanisms of conflict resolution is seen as one of the major tasks of judicial authority. ${ }^{15}$ Paolo Sartori notes that the $q \bar{a}{ }^{d} \overline{i s}$ judicial powers in Central Asia were often limited to the process of notarization of such settlements, rather than actually negotiating them. Still, this use of șulh in Central Asia does not appear to have influenced the actual formularies of transactions or contractual practice, although some of the examples introduced by Sartori related to waqf look similar to the Iranian practice. ${ }^{16}$ The Hedaya, that is al-Hidāya fi sharh bidāyat al-Mubtadī, as one of the major compilations of Islamic or rather AngloMohammedan Law, also sheds light on the various aspects of șulh, here treated under the name of Soolh or Composition. In the well-known and widely used version by Charles Hamilton, translated from the Persian, the similarities of șulh to sale or hire are mentioned, but without explicitly naming them as a practical alternative to the standard contractual forms. ${ }^{17}$ This suggests that in the case of șulh:muṣālaḥa a shared Persianate linguistic and legal heritage has less a determinative impact on the form and contact of legal documents than do differences of practice emerging from the Shii-Sunni divide.

While there are clear differences among the Sunni legal schools-in particular al-Shāfi'i and his followers introduced the analogy between sale (bay') and șulh and moved the early discussion in Islamic law over șulh towards a contractual understanding — the basic understanding of șulh as a means of

13 Following J. Wichard, Zwischen Markt und Moschee (Paderborn: Schöningh, 1995): 237. A concise discussion of 'Șulh in Shiite legal theory' see below, p. 22ff. A more detailed analysis of the concept of șulh in Shiite jurisprudence will be the subject of a separate study.

14 The understanding of șulh as a peaceful approach in the early Islamic conquests adds to the underlying semantic context, on this aspect see A. Noth, "Zum Verhältnis von kalifaler Zentralgewalt und Provinzen in umayyadischer Zeit: Die ,Șulḥ'-,'Anwa'-Traditionen für Ägypten und den Iraq." Die Welt des Islams 14 (1973): 15o-62.

15 P. Sartori, "The Evolution of Third-Party Mediation in Sharīa Courts in 19th- and early 2oth-century Central Asia." Journal of the Economic and Social History of the Orient 54/3: 313. I. Tamdoğan, "Sulh and the 18th Century Ottoman Courts of Üsküdar and Adana." Islamic Law and Society 15/1 (2008): 55-83. L. Peirce, Morality Tales: Law and Gender in the Ottoman Court of Aintab, (Berkeley: University of California Press, 2003): 120, 185-6.

16 P. Sartori, Visions of Justice (Leiden: Brill, 2017): 40, 57, in particular 214.

17 C. Hamilton, The Hedaya: Commentary on the Islamic Laws (New Delhi: Kitab Bhavan, 1994): III, 440-51. 
mediation or balancing of claims remained in the foreground..$^{18}$ The legal practice in Shiite law, however, opens up a much wider field as the following three examples from Qājār Iran vividly illustrate.

\subsection{First Example: The Murder of the Camel-Driver Qadìm 'alì}

The first case is the narrative of a peaceful solution to an impending blood feud between two villages:

The reason for writing this deed is as follows: Some time ago, a certain Qadīmalì from the village of Kakīn in the vicinity of Qazwīn, who was a camel-driver in the service of the amirr-panja Manșūr al-Salțana, had gone to the village of Mahmūdābād to let his camels graze there. Confronted by the villagers of Mahmundābād, a fight broke out, in the course of which Qadīmálī was killed. Since the murderer was not known, the claim for blood money (diya) for this murder was raised collectively against all peasants of Maḥmūdābād. The only heirs of Qadīmálī were his little daughter and his wife. After a while his daughter passed away too, and the only remaining heir was her mother, the wife of Qadìmalī. His wife named Manșur al-Salțana, his former employer, as her representative (wakil) in the task of demanding the blood money, which he did.

Now, three parts (dāng), constituting half of the village, belonged to Mīrzā Ibrāhīm Khān Wakil al-ra'āya (the ombudsman) and to a certain Raf'at al-Sultān. The peasants under the patronage of these landlords in their turn raised a claim against the looting of property and damage which had befallen the village of Mahmūdābād following this murder by the hands of peasants and armed men from the village of Kakīn. The damage and harm were brought before us [i.e. the judge] and the peasants named the Wakil al-racay $\bar{a}$ as their representative. When this dispute resulted in the reciprocal taking of oaths (and thus resulted in a stalemate), the two representatives agreed on a peaceful settlement on this issue.

Therefore, the Wakil al-ra'āyā representing the peasants of half of the village, especially the seven separately mentioned individuals, dropped their claims with regard to the pillage and damage, whether it amounted to one or 500 , or even 1000 tümān, in a contract of peaceful settlement of their own free will with Manșūr al-Salțana, for the settlement price $(m \bar{a} l$

18 A. Othman, "And Amicable Settlement Is Best": 82-3. For the Malikī school see D. Santillana, Istituzioni di diritto musulmano malichita: con riguardo anche al sistema sciafita (Roma: Istituto per l'Oriente, vol. 2., 1938): 209-20, who translates șulh as "transazione“. 
al-mușālaha a) of one sìr ${ }^{19}$ of crystal sugar (nabāt-i bandarì) and the recital of five șalawāt, praising Muhammad and his family. The other party accepted the settlement, and the contract of settlement as prescribed by the sharia became valid between them, the settlement price was handed over, and the five șalawāt were proclaimed, this took place in the month of Zīi-qa'da 1318 (February/March 1901). ${ }^{20}$

The settlement in the case of the murder of Qadìmali represents exactly what we would expect of a peaceful solution of a conflict. In a situation where oath stood against oath, where no individual culprit could be identified, where one party had already taken the law into their own hands and the danger of a blood feud between neighbouring villages appeared imminent, and, moreover, where the victim had left no male heir, a settlement was the logical way out. The 'peace' (sulh) is offered by the villagers of Mahmmudābād who relinquish their claims of compensation for the symbolic settlement price (mäl al-mușālaha) of one sir of crystal sugar, and is accepted by the other party who quietly drop their demand for blood money.

The above paraphrasing translation hides to a certain degree the stringent contractual style of the deed. This is not a court ruling, and while it includes and integrates the record of a mediation, it is primarily a contract that follows the rigid formulary of offer and acceptance that in its basic structure emulates a sale deed. Still, such examples of mușālaḥa contracts are rather the exception than the rule, as the other examples will show, and where an underlying dispute, quarrel, or set of conflicting claims cannot be discerned immediately.

\subsection{Second Example: Bībī Fāṭima Sells a Shop to Finance Her Pilgrimage to the 'Atabāt}

The second example of a mușālaha-deed comprises a sale between relatives, but in addition addresses questions of inheritance and includes a number of unusual, special stipulations:

The reason for writing this deed is the following: Bībī Fāțima, the wife of the late Ustād Muḥammad Riżā the Dyer, transferred through a contract of șulh (muṣālaḥa namūd) to Ustād Ḥâjjī Bābā the Goldsmith, who

19 Measurements of weight: 1 man is about $2.9 \mathrm{~kg}$ (see below), $1 \mathrm{sir}$ is 1/40 man, i.e. ca. 74 gr.

20 H. Rajabzade and K. Haneda, ed., Fifty Five Persian Documents of Qajar Period (Tokyo: ILCAA, 1997): 126-7. Rajabzade provides the text edition with facsimile, the paraphrasing translation is mine. Places and individuals mentioned are of no concern in the present context. 
is the nephew of her late husband, one complete dyeing shop (dukkān) located in the New Bazaar, a description of its boundaries is included, for the settlement price (māl al-mușālaha) of 30 tümān of current currency, which is to say 300 pieces of Șāhib-qirāns, under the following conditions:

He has to provide stone slabs over five graves [of the family] on a complimentary basis (ba-țariq-i ta'äruf) and to provide for four years of prayers and fasting (șaum wa-salät) on behalf of four deceased family members, as well as two sessions of mourning rituals (ta'ziya-dāri $)$. Another stipulation is that he will provide all necessary equipment for the afore-mentioned Sayyida when she goes on pilgrimage to the 'Atabāt shrines in Iraq; this includes shoes, a tent (chädur-i shab), and copperware necessary for traveling. From the mentioned amount he shall pay 10 tümān after 10 days and the rest after two months, and in case the aforementioned Sayyida desires to depart speedily before the mentioned time span of payment, he shall pay all 30 tümān in cash and forward it to her.

After this transaction Ustād Bābā himself offers a mușalaḥa-contract covering all his possible cancellation rights (khiyārāt), among them the right of cancellation because of fraud; for the settlement price (māl al-mușālaha a) one man of wheat and 100 dinnār in cash, the formal conclusion of the two mușālahasas was finalised through offer and acceptance (ïjäb wa qabül) in Arabic and Persian on 1 Șafar 1248 (30 June 1832). ${ }^{21}$

This contract is outwardly a sale in the form of a mușālaha, but the circumstances hint at a pre-arranged transfer of expected inheritance to a nephew, combined with a guarantee of financing a pilgrimage and other religious activities. Interesting is the inclusion of a second settlement-contract that removes all rights of cancellation for a nominal settlement price. This is a frequent construction in sale contracts of the late nineteenth century to exclude later legal procedure and attempts to rescind agreements in court. ${ }^{22}$ So we see the case of a double, reciprocal contract of composition.

Sayyida Bībī Fāțima appears as a candid widow with very clear aims of travel. Still, without further background information, it is difficult for us to grasp the reality behind this legal construction. Her nephew might have followed in the footsteps of her late husband, continuing the family business in running the dyeing shop and funding his beloved aunt a long desired pilgrimage. Equally

\footnotetext{
21 M. Žbabịhī and M. Sutūda, Az Āstārā tā Istārbād. Vol. 7: Asnād-i tārīkhì-yi Gurgān (Tihrān: Intishārāt-i Anjuman-i Āṣār-i Millī, 1354sh/1975): 70-1. Again, the paraphrasing translation is mine; the volume includes the edited text and a short summary. 
probable is the possibility that relatives, including her nephew, refused to take care of family graves and wanted to remove Bībī Fāṭima from her husband's shop-sending her off to the Shrines in Iraq might have been a way to ensure her compliance. The additional second mușālaḥa suggests that the parties were not operating on a basis of trust.

\subsection{Third Example: A Rental Contract with Legal Small Print}

The third sample is a contract of rent or lease issued by Zahīr al-Islām, the chief guardian (mutawallībāshī) on behalf of the trustees of the shrine of Imām Riżā in Mashhad, dated Rabīi II 1334 (beg. 9.2.1916).

After Praise and Commendation: The trustees of the Āstāna-yi Muqaddasa (the Sacred Threshold) transferred with the permission and signature of the Hujjat al-Islām (= the mutawallībāshì) through a contract of settlement (mușālaḥa namūdand) to Mīrzā Muḥammad b. Ḥājjì ‘Abd al-Husayn, a merchant from Tehran resident in Mashhad, the complete produce (hâașil wa-manäfi) of half of the hamlet Bìldar, half the hamlet of Ābkūh, and all of the hamlet Sarbarq, all of them waqf property of the Holy Shrine, with all that pertains to it from a sharia or customary legal view, from autumn of the current year, the Year of the Rabbit 1333, and the harvest of the Year of the Crocodile 1334, onward over a period of full seven years, including both summer and winter harvests, for the settlement price (māl al-mușālaha) of 1001 tümān in cash and the amount of 215 kharwār, 6o man of grain and 21 kharwār of straw, which amounts to a defined yearly rate [details being calculated].

Of special interest, however, in this contract of lease are a number of special-and sharia-conformant-stipulations that are an integral part of the contract and are introduced thus:

"in the course of the contract, the following conditions were laid down" ( fì żimn al-'aqd shurūt-i shar'ìya wāqi' shud):

- All agricultural expenditures (makhārij-izirāa atì), including the cleaning and upkeep of the water channel (qanät) are the obligation of the one accepting the settlement for the whole period.

- In the case that the payment of the settlement price (mäl al-șulh) is delayed, whether completely or in part, whether concerning payments in cash or in kind; or in case the one accepting the settlement passes away, while the trustees of the waqf have no trust in the heirs of the aforementioned; or the lessee transfers activities to another person 
without the permission of the waqf's trustees; or there are manifestations of deceit and fraud in the endowed object; in all these cases the right to dissolve $(f a s k h)$ the muṣalaha rests with the trustees of the waqf.

- In the case that marauding troops enter the land or hail damages the harvest to a degree that the landlord's share in summer and winter amounts to less than half of the settlement price of that year, the trustees of the waqf will seize the complete harvest and the outstanding amount will be considered as a reduction for the lessee, while the amount of six kharwār of grain will be provided as seed from the property of the Holy Shrine. However, it remains the obligation of the lessee to return this amount at the end of the total rental period, together with the object of șulh [i.e. the land rented out].

- In the case that the mentioned stipulations is violated and results in a dissolution of this contract, the trustees of the waqf are entitled to seize the seed that the lessee has stored from his own property in the villages in the range of 1 man to 20 kharwār. ${ }^{23}$

In the previous example, the muṣalaḥa emulated a contract of sale; here it reproduces a contract of rent or lease that evokes decisively modern connotations in its small print. The management of the Holy Shrine as the lessor attempts to place the onus of possible loss on the lessee; it reserves the right to dissolve the contract in various instances and the term of lease is short in comparison to medieval and early modern contracts. Overall, the contract appears to be rather disadvantageous for the lessee.

The three examples presented all carry special features and already provide a rough idea why the muṣalaha-contract was so popular. Especially the third example suggests that it must have been easier to insert special conditions $(s h u r u \bar{t})$ in a contract of settlement or composition than to incorporate them in the more rigid formulary of a traditional contract of lease.

It would, however, be wrong to assume that all mușālaḥa contracts were so specific and detailed. In fact, the large majority of them can be seen as simple contracts of sale or exchange as in the model formulary provided in Beck's grammar. The contract of șulh is able to accommodate a wide variety of possible practices, and the following list is far from exhaustive:

- a 'real' settlement in case of reciprocal claims, disputes or debts

- a reallocation of landed property to alleviate agricultural use

23 F. Jahānpūr, "Barrasī-yi chand ișțilāḥ dar mușālaḥa-nāma-hā." Ganjīna-i Asnād 11/41-2 (1380sh/2001): 79-83. 
- the settlement of inheritance disputes or redistribution of inherited property, often in connection with the conclusion of testaments

- granting, relinquishing or transferring rights resulting from marriage contracts, in particular 'dowry' (mahr)

- a contract of sale

- a contract of rent or lease

- a service or work contract (i.e for religious services or pilgrimages); partly constructed as a conditional clause (sharț) in a mușālaḥa

- a contract of donation (hiba) often as a fictitious contract for a nominal amount

- the combination of several contractual forms in one contract

- the insertion of special clauses (shurüt)

- the prevention of legal claims, litigation or cancellation

This variety and the widespread use of șulh /muṣālaḥa has been captured equally well in the examples chosen by Omid Reza'i in his Introduction to Shari'a Documents. His emphasis is on the 'results' (natāyij) provided by this universal contractual form that seems to be applicable on every occasion. Reza'i shows that a mușālaha can deliver the result or outcome of a contract of sale, of rent or of donation-but its advantage lies in the fact that certain conditions can be avoided in preferring this type over the 'original' contractual form. For example, a donation in the traditional form of a unilateral hiba ('gift'-contract) is to a certain degree revocable and can be rescinded (faskh), whereas the contractual form of șulh delivers the same result, namely the transfer of property without 'real' compensation, but is bilateral and binding (lāzim).

Reza'i's first and opening example is thus a contract concluded between a woman and her husband wherein she transfers all her paternal and maternal inheritance to him for a nominal amount. Such a transfer would not have been possible within the framework of a unilateral gift-contract (hiba), as the transaction covers several properties and indirectly involves inheritance law. ${ }^{24}$ The second and third examples that Reza'i offers show a mușālaḥa contract emulating a rental contract (ijāra) and a mușālaḥa contract emulating a final and irrevocable sale (bays $i$ qat $t i$ ) respectively. ${ }^{25}$

The dominance of muṣālaḥa contracts in the late Qājār period is not simply a subjective impression gained in passing from working in various archives and

24 More on the use of șulh /musāahaha contracts to transfer property and avoid inheritance laws below in the conclusion.

25 U. Riżāc̄ī, Dar-āmadī bar asnād-i shar 'ī-yi dawra-yi Qājārr (Tokyo: ILCAA, 2008): 150-63, with further references. 
looking at collections of edited documents. ${ }^{26}$ As Nobuaki Kondo has shown in his illuminating studies on Tehran sharia courts and their registers, the preference for șulh as a legal tool can also be demonstrated statistically. He has drawn on three registers compiled by two jurists, Sayyid Muḥammad Ṣādiq Ṭabāțabā'ī Sangalajī, covering the years 1867-68 and 1875-79 (Sangalajī I and II), and Shaykh Fażlallāh Nūrī, covering the years 1886-89. ${ }^{27}$ These registers include records of commercial transactions (sale, conditional sale, loan, lease) and family law (marriage, divorce), as well as the resolution of disputes and legal verdicts, in short the whole range of Islamic law. Kondo distinguishes șulḥ/mușālaḥa settlements of disputes (including the settlement of dowry claims) from transactional mușālaḥa contracts emulating sale or lease. ${ }^{28}$ In the case of simple sale transactions, the muṣālaḥa contract type was employed in more than two thirds of all cases from his corpus. ${ }^{29}$

\section{3}

\section{Șulḥ in Shiite Legal Theory}

Let us return to the legal definition of șulh and the actual basis for the classification of mușālaḥa as a contract. Early Shiite legal literature is in fact very close to its Sunni counterpart in its description and categorisation of șulh. Thus Shaikh Țūsī in his al-Mabsūt of the eleventh century denies șulh the status of an independent contract and declares it to be a subdivision or branch $($ far $)$ of other contracts, and he distinguishes these subdivisions ( fur $\bar{u}$ ) as being those of sale (bay ), remission of debt (ibrä), rent (ijāra), loan ('ârīya), and donation (hiba) $\cdot^{30}$ In the thirteenth century, Muhaqqiq al-Hiillì's Sharāyic al-Islām abandons this view and declares that șulh should not be regarded as a subdivision of other contracts, even if it emulates the benefits of these contracts. That șulh (composition) is an independent institution in Shiite law was by now the majority view and also differentiated Shiite law from the Shāfīi tradition. ${ }^{31}$

26 See note 7 above.

27 Kondo, Islamic Law and Society in Iran: 43. As courts and registers were considered private collections, few have survived and research on them is only beginning.

28 On mușālaḥa as settlement see Kondo, Islamic Law and Society in Iran: 52-3.

29 N. Kondo, Islamic Law and Society in Iran: A Social History of Qajar Tehran. London: Routledge, 2013): 75 (table 5.1). The use of muṣālaha was less frequent for conditional sales and leases (i.e. credit loans): 78 (table 5.5) and 81 (table 5.9). He suggests a gradual shift from mubāya'a to muṣālaḥa that occurred first with normal sales before being extended to conditional sales.

30 M. b. al-Ḥasan 'Alī al-Ṭūsī, Al-Mabsūt fì fiqh al-imāmōya, ed. M. Taqī al-Kashfī (Tihrān: 1350sh/1970), vol. 2: 288-311.

31 P. Owsia, Formation of Contract (London: Graham \& Trotman, 1994): 360-1. 
Despite this more open definition of șulh, the discussion of șulh in its practical application was rather limited around this time and remained indebted to older traditions. Thus, a large part of Muhaqqiq's chapter on șulh deals with what we would call nowadays 'building regulations', such as the question of whether the owner of a house is allowed to affix to his house a veranda that reaches out into public alleys. ${ }^{32}$ This open definition of șuḷ remains quite stable and the major and monumental nineteenth-century commentary Jawāhir al-Kalām on Muhaqqqiq al-Ḥillī has astonishingly few new examples or questions to add to this in its chapter kitäb al-șulh. ${ }^{33}$

A new step in the legal approach to șulh is taken in the Safavid period, by authors such as Shahīd al-Awwal, Bahā al-Dīn al-Āmilī, and Ḥurr al-Āmilī. In an attempt to popularise the understanding of șulḥ, Bahā al-Dīn provides the henceforth standard definition that șulh is a contract that the lawgiver has established in order to settle conflicts between men. According to him, șulh can then be divided into three major categories: first, șulh between Muslims and the ahl-i kitāb, i.e. in connection with jihäd; second, șuḷ between husband and wife in a divorce suit; and third, șulh between two parties arguing over property. Here, șulh is a binding (läzim) contract that follows clear conditions, and has to be expressed in the form that we know already from our previous examples: "I settle (mușalaha kardam) the following dispute with you ( $b a t u$ ) for the fixed amount of ....".34

As we see, there is a clear evolution of a distinct Shiite concept of șulh over the centuries that leads to the definition of șulh or mușālaha as an independent, binding and universal contract that can be applied in a wide variety of circumstances. However, the question remains whether the legal literature of the nineteenth century actively supports or legitimises the preference of the mușālaha contract over other contractual forms. In other words, does the legal literature comment on what can be glanced from the legal practice? This is crucial as the mujtahid-jurists that run the sharia courts stand in a close studentteacher relationship to the main authorities of Shiite law, and sometimes are both juristic authors and practitioners. While there is a steady growth of legal advice literature, printed in Arabic and Persian, there is also a reluctance to

32 Hịllī al-Muhaqqiq al-Awwal, Tarjuma-i fārsīi $i$ Sharāyic al-Islām, trans. Abū al-Qāsim b. Aḥmad Yazdī, ed. M. Taqī Dānish-Pazhūh (Tihrān: Intishārāt-i Danishgāh-i Tihrān 1358sh/1997), vol. 1: 267-54.

33 M. Ḥ. Najafì (Șaḥib-i Jawāhir), Jawāhir al-Kalām fì sharḥ Sharāyi al-Istām: Volume 26: Kitāb al-ṣulh (lithograph n.p. 1274q/1858).

34 Bahā' al-Dīn Muḥammad 'Āmilī. Jāmi'i 'Abbāsī: risāla-yi 'amalīya, bā ḥavāshī-yi hasht faqūh-i ālìmaqām, Qum: Daftar-i intishārāt-i Islāmī, 1388sh/20o9):226-7. Following Arabic grammatical usage, the legal wordings in Persian also use the preterite forms. 
further expand the Safavid definition of șulh and especially in the twentieth century a return to more traditional topoi.

Two examples might help to make this point clearer. The first such example is taken from a typical Question \& Answer work (su'äl wa jawāb) from 1842: a question posed to and answered by one of the most famous and powerful $m u j$ tahids of Qājār Iran, Muḥammad Bāqir al-Shaftī.

A woman has transferred (mușālaḥa namūd) her properties, consisting of a house, land etc. to her son-in-law under the condition that the recipient carries out a number of activities after her death, such as a pilgrimage, prayers and fasting and Koran recitations. Now the recipient, who shall be called Zaid, comes and in his turn transfers as a mușālaha all these properties on to his young son who is a minor, without any conditions. Then once more, assuming the custody of his son [he feels guilty] and in the name of his son transfers as a musālaha some of the properties [back] to the descendants of the woman [re-]inserting the previous conditions. Is the second mușālaha valid or not, and does the father in this case really have the automatic guardianship of his son? ${ }^{35}$

Shafti concludes in his reply that all three contracts of composition are valid and unproblematic, even the transfer on behalf of his minor son-unless blatant corruption is apparent. He emphasises, however, the question of intent as the crucial legal problem in this case: Did the woman who concluded the first muṣalaha intend that only the first contractual partner should carry out the religious tasks on her behalf, or did she agree to a transfer on to her heirs at a later point? If there is doubt on this point, any further contractual agreement becomes void. In earlier books of the Q\&A type and in most legal Shiite handbooks, the chapter on șulh is rather insignificant and small. The fact that someone like Muḥammad Bāqir al-Shaftī, a fierce protagonist of 'ulamā independence in the city of Isfahan, reserves a relatively large space for questions on șulh in his book might be seen as an acknowledgement that șulh had become more important by the time this book was composed. ${ }^{36}$

What one can deduct from the above is that actual transactions, such as the one we encountered in the case of Bībī Fāțima, were discussed in the applied

M.B. al-Shaftī, Kitāb-i su’āl va jawāb (Tihrān 1258q/1842): 297 (Kitāb al-ṣulḥ: 286-303). These works might be compared to Sunni fatwa collections, although one has to be careful with the analogies, as the shiite understanding of a fatwa and the institutional background of shiite juristic practice is quite different.

$3^{6}$ On Shaftì see I. Schneider, "Muḥammad Bāqir Šaftī (118o-126o/1766-1844) und die Isfahaner Gerichtsbarkeit", Der Islam 79/2 (2002): 240-73. 
legal literature of the nineteenth century. The more theoretically inclined works of jurisprudence, however, maintained the idea that șulh was bound to opposing claims, debts or obligations. On this abstract level, practical examples do not play an important role, and the main emphasis of the jurisprudents is to stress that the general rules of riba and other contracts also apply to șulh. An example taken from Khomeini's twentieth-century legal handbook for laymen Taużĭhal-masäil may illustrate this point:

If someone gives his sheep to a shepherd, so that he takes care of them, for example for one year, and he [the shepherd] uses their milk and provides a certain amount of butter to him [the original owner of the sheep]; and the owner of the sheep settles (sulh kunad) the sheep's milk as equivalent to the efforts of the shepherd and the provided amount of butter, it is legally correct. If, however, he should lease the sheep for one year so that the shepherd can use the milk, and in exchange, provides an amount of butter, it is problematic. ${ }^{37}$

This sounds like a casuistic approach of jurists removed from actual practice, as few landlords and peasants would conclude a formal written contract of lease over a flock of sheep. Crucial in this argumentation is the opposition of two contractual forms: that of șulh vs. that of $i j \bar{a} r a$. As an ijära such an exchange is not allowed, since no fixed rental price is given, whereas the same construction is valid as a sulh, since diverging claims can be simply balanced. One has to be aware that Khomeini in the twentieth century, argues not anymore as a mujtahid ruling in his own court, but as a judicial expert and scholar.

Beyond the apparent flexibility of șulh as a universal 'one-fits-all' contract, the genesis of mușālaha contracts in legal practice from the seventeenth to the nineteenth century suggests yet another possible reason behind the success of this contractual form. We saw already in our second example with Bībì Fāțima that the need was felt to safeguard a contract and its legal effects from litigation, claims and disputes. The standard way to prevent claimants from challenging a sale, lease or transfer of property was to include an additional, pre-emptory 'settlement/composition' in advance. Most frequently this was clad in the formulaic prevention of annulment because of fraud (khiyār

37 R. Khumainī, Risāla-i tau̇̇ị̆ al-masāill (Tihrān: Irshād-i Islāmī, 1371sh/1992): 291 (Q2163). 
al-ghabn) - but other such pre-emptive formulae mention explicitly disputes $\left(d a^{c} w \bar{a}\right)$ and exclude legal representatives, relatives or third parties.

This option of inserting an additional, pre-emptory muṣālaha occurs relatively early on and can be found already in deeds from the Safavid period. The edited specimen in the appendix from $1156 / 1743$ is excellent as it shows in its clear and concise style both the similarities to the formulary of Beck's Konversationsgrammatik, a hundred and fifty years later, and the way a mușālaḥa was inserted as a device to endorse and safeguard an ordinary sale contract. In its outer appearance, this deed from the era of Nādir Shāh Afshār (r. 1736-47) is a contract of sale over land in Khorasan that is clearly marked as a mubāya'a. Apparently, the contractual parties were afraid of opposing claims and disputes and thus they secured the sale with a double legal contrivance. Any imaginable legal dispute $\left(d a^{i} w \bar{a}\right)$ that could come up in the future is settled in advance through a 'settlement/composition' (mușālaḥa), raising the sale price from 70 tümān to 75 tümān —and as this was still not enough guarantee, the selling party in addition gave these possible claimants rights in lease for a total period of ninety years, resulting in a final total price tag of 8 o tümān. ${ }^{38}$

I would suggest that over time it had become more efficient in daily notarial practice to skip one step and to simplify this process of combining a sale with a composition in formulating a sale transfer from the start as a mușālaḥa. The aspect of avoiding litigation, disputes and claims, however, must have been particularly appealing in later Qājār Iran where legal disputes in and between different legal experts and courts multiplied. The rise of the musaalaha should then be seen as emblematic for a society that became more and more 'quarrelsome' and confrontational. ${ }^{39}$

A close observer of judicial practice and realities in the 1940s and early 1950s was Ann Lambton. Familiar with both the situation prior to modern legislation and the new Civic Code introduced under Reza Shah, she pointed out one cause for the attractiveness of șulh-transactions: transfer of properties in order to circumnavigate inheritance laws and restrictions:

One of the ways by which the excessive subdivision of estates consequent upon the laws of inheritance is to some extent limited is by the owner making gifts of his estates during his lifetime to one or more of his

38 The latter is indeed a quite confusing construction, but the summary of the sums received and acknowledged leaves no doubt that the 'composition' and the 'lease' are actually bound together.

39 More on this and litigations in the excellent dissertation by Z. Bhalloo, 'The Qajar Jurist and His Ruling: A Study of Judicial Practice in Nineteenth Century Iran' (Oxford:Wadham College 2013). 


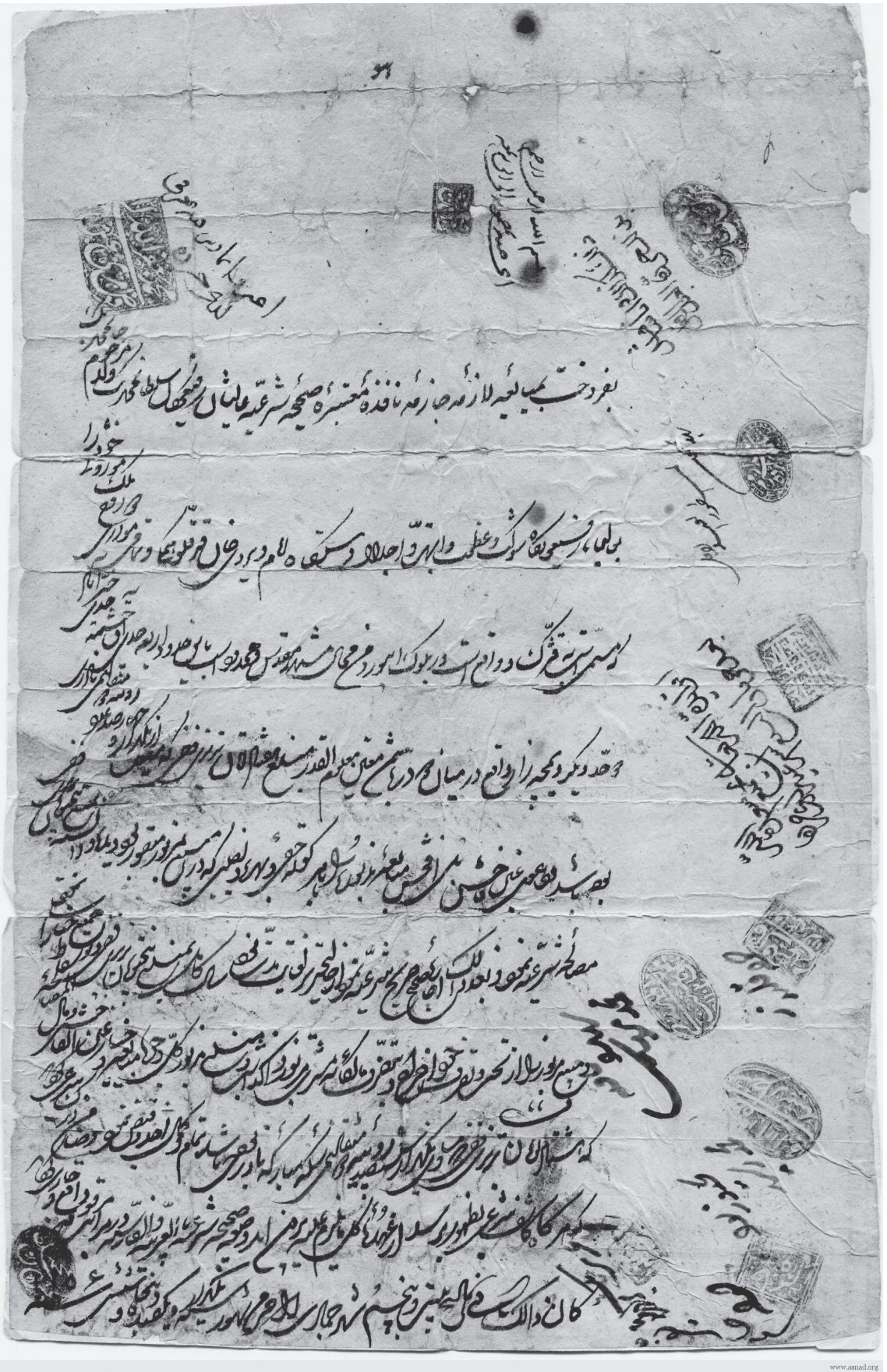

FIGURE 2 Combined contract of sale, lease and composition (1156q/1743) 
heirs. The form which this transaction takes, however, is not usually that of a gift, but rather of 'conciliation' or șulh. ${ }^{40}$

Her observation on șuḷ or 'conciliation' is congruent with our own findings:

'Conciliation' in the Civil Code is extended to cover a rather wider field than in the exposition of al-Muhaqqiq [see above: al-Muhaqqiq al-Hillī, Sharāyi' al-Islām] who appears to regard it solely as means to terminate a dispute. ${ }^{41}$

Interesting is her interpretation that sees the codification of the practice of șulh as an acknowledgment of this much wider field—in other words taking the view that modern legislation followed and confirmed the developments in Shiite sharia law of the late nineteenth century. In Lambton's view, it has been primarily the easy method of transferring property in order to prevent the subdivision of estates through inheritance laws that made the contract of șulh so attractive. This argument is convincing as building and conserving estates is one of the main threads that runs through most legal transactions and disputes. However, as we have seen, it is by far not the only use of șulh.

\section{Conclusion}

The legal category of șulh and the contractual/transactional form of muṣalaḥa can be approached through different angles: one is of course the legal perspective of Shiite Islamic law, from its formative period up to its partial canonization in the Qānūn-i Madanī, the modern Civil Code of Iran from the 193os. Another one is that of legal practice and the question of how this particular form of contract has been used and to what purpose. The third angle is a diplomatic or formulary perspective, considering in what ways the particular physical

$40 \quad$ A.K.S. Lambton, Landlord and Peasant in Persia (London: Oxford Univ. Press, 1953): 200.

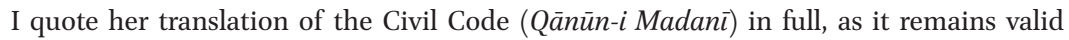
under the Islamic Republic with only minimal variations. Note her rendering of the term șulh as 'conciliation' instead of settlement or composition: "'Conciliation is possible either in order to settle an existing dispute or to prevent a potential dispute concerning some transaction or other or which might arise over something else' (art. 752). For the 'conciliation' to be valid both parties must be competent to undertake the transaction and to take possession of the subject of the 'conciliation' (art. 753). A 'conciliation' without recompense is valid (art. 757). The right of pre-emption is not established in the case of 'conciliation' (art. 759). It is a binding agreement (art. 760), but 'conciliation' transacted under duress is not valid (ar. 763)."

Lambton, Landlord and Peasant in Persia: 200. 
contracts of mușālaḥa were written and whether they constitute a different form of contract also in this regard. Among these approaches, the middle one is the most difficult, as — at least until now — we have no ego-statements by the practitioners of law on why they chose one form of contract over another. It would be nice to have a mujtahid's diary that would explain why in his judicial practice over the years he had recorded more and more sale transactions in the form of a muṣālaha. In many instances we are indeed forced into open speculation and hypothesizing, as we can only second-guess the real stories behind many written documents.

The legal literature of the nineteenth century shows, at least in part, that there is a clear recognition of the popularity and wide-spread application of șulḥ/muṣālaḥa in this period. But while the practice is recognized, this does not mean that there is also a theoretical elaboration of why this phenomenon occurred. In other words, legal literature does not explain why so many practising jurists, such as Shaftī in Isfahan or the Sangalajīs in Tehran, chose to formulate most of their transactions in the form of this "universal contract", or Sayyid al-uqūd ("The Lord of Contracts" as it is also known, instead of recording a sale as a contract of sale (a mubāya'a) or a lease as a contract of rent (a mu'äjara).

Since we will not find a clear answer in the sources, we have to consider which factors may have played a role in this development. The influx of a vernacular use of language, such as mușălaha namüd with the unspecific meaning of "transferred", into legal formularies is certainly a case in point.

As the papers collected in this special themed issue are devoted to transactions, my main hypothesis is related to an until now not yet fully understood process of an extension of the legal sphere in late nineteenth century. Practitioners-jurists and clients, courts and officials, laymen and expertswere using law and legal documentation on a previously unknown scale. With an extension of the legal sphere and its connection with more and more economic transactions, it is only to be expected that increased flexibility in contractual forms proved to be advantageous. Diverging claims could be transferred, settled and negotiated much more easily and complicated constructions involving inheritance, lease sale and nominal sales could be combined. In general, the holding of property titles became more and more important-it did not suffice anymore to simply exercise control (tașarruf) over property shares, they had to be documented —and mușālaḥa contracts were a convenient way to document and legalize already existing divisions and holdings of property prior to further legal actions (e.g. establishing a testament or an endowment). 
In the same way, parties could avoid tiresome and long-drawn legal disputes in court: one of the pervasive origins of a muṣālaḥa seems actually to derive from an additional safeguarding clause, inserted into other contracts; a practice we see and witness from the Safavid period onwards. Thus, to exclude disputes $\left(d a^{i} w \bar{a}\right)$ and claims for annulment of contract (faskh) for various reasonsmost common later arising concurrent claims of ownership over the object sold—an additional, pre-emptive șulh-clause proved useful. In the past, settlements were often included in normal sale or rent contracts to void and exclude later claims - thus a settlement would preclude possible later court claims.

Using the muṣālaḥa type for a wide variety of legal transactions can be regarded as the outcome of a longer process that saw the shift from an included, additional muṣalaha within a sale contract to a replacement of the former by the latter. Why compose a contract of sale (mubāya'a) and secure legal liabilities through an inserted sulh clause if the outcome of the whole transaction can equally well — if not better and more easily — be achieved directly through a mușālaḥa contract?

This process in the contractual law of transactions in nineteenth-century Iran was linked closely to the unique development of an independent Shiite judiciary and its courts. While the concept of șulh as settlement or mediation was wide-spread in the Persianate world, the use of șulh/mușālaḥa to emulate a variety of contracts did not catch on in other regions influenced by Persian as a legal language, neither in Central Asia, nor in India. The establishment of secular and authoritarian Pahlavi rule and the introduction of codified law in the 1920 and 30 s is often regarded as a sharp break with traditional jurisprudence and legal practice. The use of șulh/muṣalaha shows that this is not correct, since the traditional legal definition was incorporated verbatim in the new Civil Code of modern Iran.

Of course, 'real' settlements and 'peace' agreements could also be negotiated within a mușālaḥa as we saw above. A clear indication of an amicable settlement or a transfer of rights are symbolic statements of settlement price such as sweets or salutes to the prophet. Giving one $\operatorname{sir}$ (c. 75 gr.) of crystal sugar is a token price that can be interpreted as a symbolic 'sweetener' for a deal that concluded negotiations. In many instances it is difficult to judge from the contract itself what is the story behind the settlement contract-a lot of guesswork is needed and without knowledge of the broader context this can be risky. Especially in the case of transactions within families and between family members, often involving women in dependent situations (widows, wives, daughters), mușālaḥa-contracts may have been merely a facade, veiling and hiding pressure. On the other hand, the presence of women in so many 
contracts of the late Qājār period can be seen as evidence of more legal awareness and growing economic independence. ${ }^{42}$

The emergence of the muṣālaha occurs at the same time as the growing independence of the 'ulamā from state institutions and offices. It also goes hand in hand with the numerical growth of practising jurists (i.e. mujtahids) and therefore the explosion of legal disputes in Qājār society. Especially towards the end of the nineteenth century, previous trust in the mechanisms of judicial procedure became weaker, whether state exercised justice or justice mediated and disbursed through the 'ulamā. Both were increasingly perceived as corrupt, inefficient and unjust. The same time period also sees the first attempts to establish official state-operated secular courts and to begin state-led judicial reforms. All in all, there can be no doubt that the dominance of the musālaḥa as a widely applicable 'universal contract' is both a product and a sign of larger developments in the second half of the nineteenth century.

\section{Appendix: 2 Edited Documents}

1. Qabāla-Mușālaḥa from Sebastian Beck (1915) via Shīrāzī Ḥamzawīs Sayyid al-inshä'-i naw-zuhūr (1909)

\section{Persian Text}

صورت قبالهنايجه شرعى

غرض از تحرير و تسطير اين كلمات واضحة الدلالات آن است كمه در بهترين وقت از مان

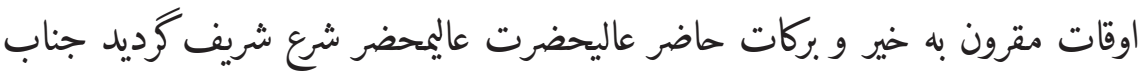

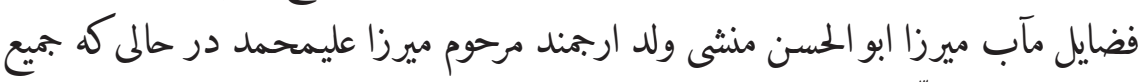

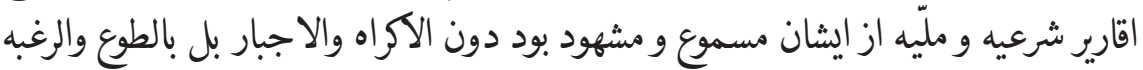

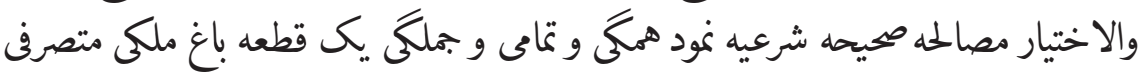

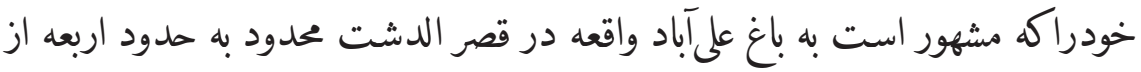

42 Another way to get an idea on the wide use of mușālaḥa contracts by women (and including women) is to browse the collections of Harvard University's Digital Archive Women's Worlds in Qajar Iran at http://www.qajarwomen.org (accessed 01.02.2020) for "settlement" and "contracts." 


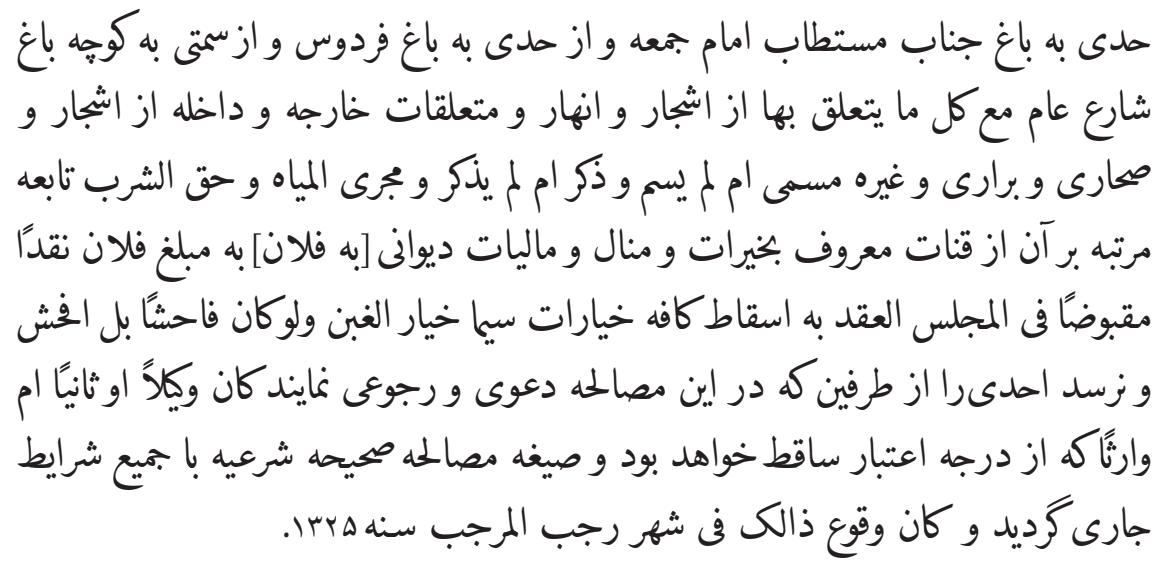

\section{English Translation}

Formulary of a standard deed according to sharia law

The purpose of writing and composing these words of clear proofs is the following: In the best of times, propitious to good works and blessings, he appeared before the eminent and noble sharia court, his excellency, the repository for all virtues, Mīrzā Abū al-Hasan munshī, son of the late noble Mīrzā 'Alī-Muhammad, in a state whereby he audibly and visibly fulfilled all the legal and religious conditions, without any force or coercion, but with full voluntary intent and free will, he offered in correct and sharia-conformant composition, all and everything of one piece of a garden owned by him and in his possession, which is known as the Bāgh-i 'Alī-ābād, situated in Qașr Aldasht, limited by boundaries on four sides, on one boundary by the garden belonging to the excellent Imām Jum‘a, on one boundary by the Bāgh-i Firdaws, and on one side by the garden alley off the main street, with all that belongs to it of trees and water canals, and whatever is part of it inside or outside, such as trees, uncultivated land and fields, etc., whether mentioned or named explicitly or not, and all water supplies and rights related to it from the qanāt known as charitable, and property and dīwani taxes, [to such and such], for such and such amount, in cash and received in the contractual session, letting fall all possible causes of annulment, be it the annulment because of fraud, and even of the worst kind, and none of the two parties that [are mentioned] in this composition shall raise a complaint or attempt a withdrawal, whether through a legal representative, a second party, or an heir, which will have nil credibility and the contractual form of a correct and sharia-conformant composition with all conditions became valid, and this took place in the month Rajab of the year 1325 . 
2. A combined deed with a contract of sale (mubāya'a) from Khorasan, secured through an additional mușālaḥa and a contract of lease (ijära), dated 25 Jumāda II $1156(16.8 .1743)^{43}$

\section{Persian Text}

ا بفروخت بمبايعهُ لازمهُ جازمه نافذه معتبره صحيحه شرعيّه عاليشأن رفيعمكان

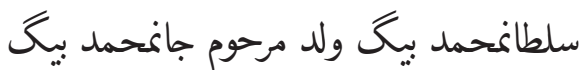

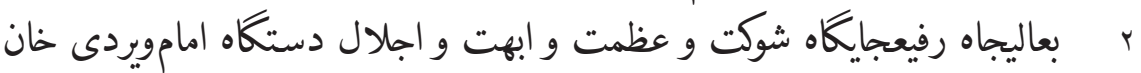
قرقلو همى و تمامى موازى دو زوج ملكى موروثى خودرا

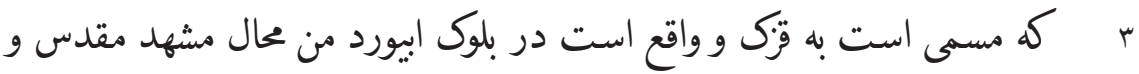

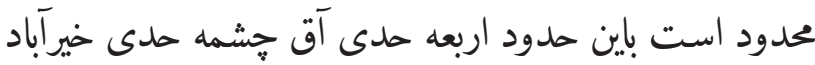

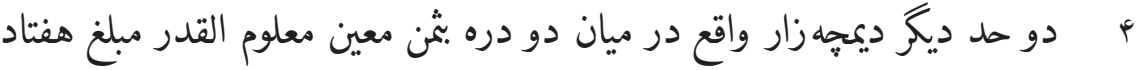

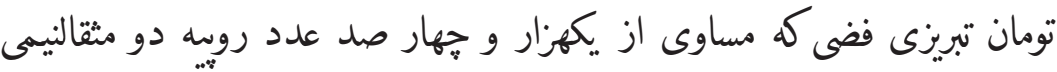

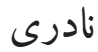

ه بوده باشد و دعوى غبن فاحش بل الفش مبايعه مزبورهرا با هركنه حتى و بهره و

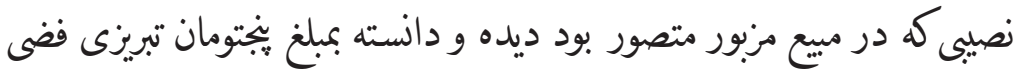

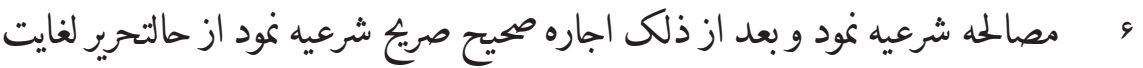

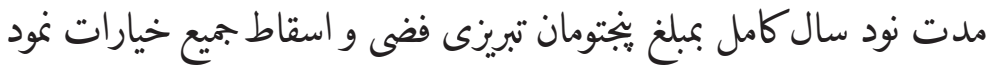

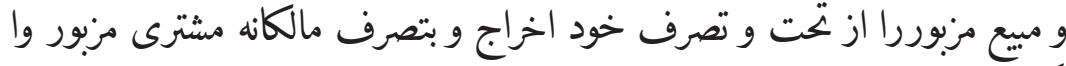

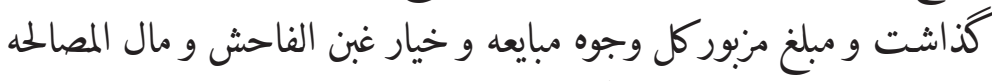

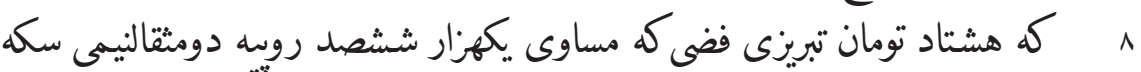

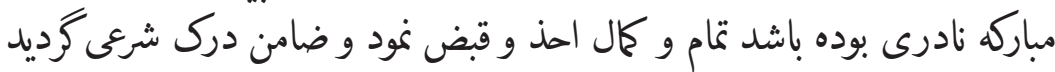

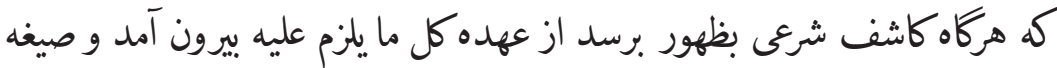

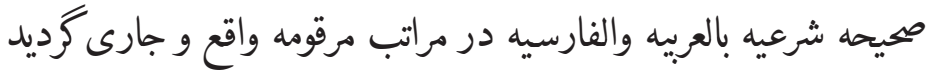

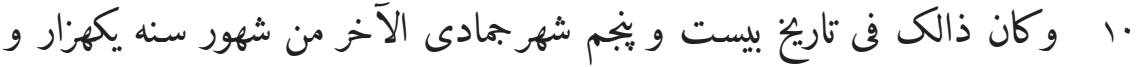

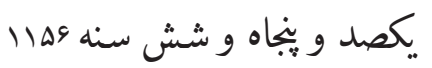

43 Private Collection of Kioumars Ghereghlou, here http://asnad.org/en/document/1015 (accessed 01.02.2020). 


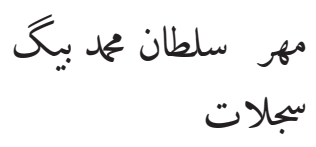

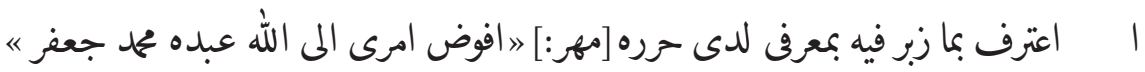

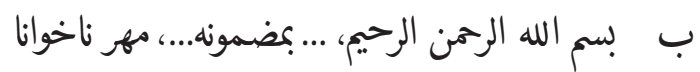

ج ذالكذالك و انا شاهد بذلك حرره العبد الاقل، مهر نا خوانا

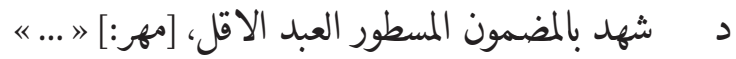

هـ اقر ايده الله تعالى بجميع اسعده الله بعد جريان الميع الشرعية لدى حرره، [مهر:]

«...

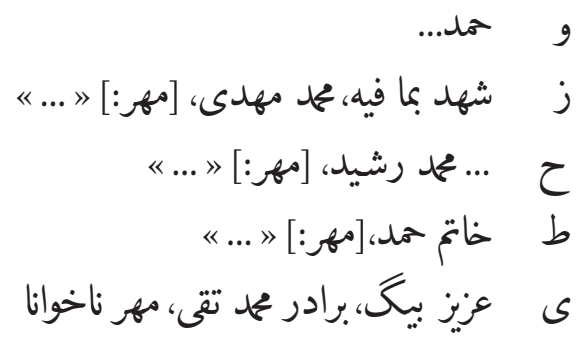

\section{English Translation}

$\mathrm{He}$

1 He sold with a binding, obliging, effective, acknowledged and legally correct sharia contract of sale (mubāya'a), the honourable and highranking Sulțān-Muḥammad Beg, son of the late Jān-Muḥammad Beg,

2 to the noble and elevated, repository of dignity, magnificence, grandeur and honour, Imāmvirdī Khān Qiriqlū, ${ }^{44}$ all and everything of two pieces of his own inherited landed property

3 which is named as Quzak and located in the area of Abīward from among the districts of Mashhad-i Muqaddas, and limited on four sides, one of them (the village of) Āq Chashma, one (the village of) Khayrābād,

4 and on two other sides on (the village of) Daymcha-zār, located in between two vales, for the clearly determined price over the amount of seventy tümān-i tabrīzi in silver coinage, equivalent to 1.400 pieces of Dumişāânimī Nādirī rupees,

44 Again, the historical background to this document can not be explored in detail. Abīward lies to the north of Mashhad, close to the present border of Turkmenistan; on Imāmvirdī Khān see L. Lockhart, Nadir Shah: A critical study based mainly upon contemporary sources (London: Luzac, 1938): 116, 215 . 
5 and (furthermore) any litigation because of fraud, and be it of the most abominable type, over the mentioned contract of sale, with any kind of claim, usage or profit imaginable in the sold object, seen and understood, for the amount of five tūmān-i tabrìż in silver

6 he made a sharia-conform composition (mușālaha) and after that he concluded a legally correct and sharia-conform contract of lease (ijāra), from the time of writing to the end of a period of ninety years in total, for the amount of five tümān-itabrïzì in silver, and he excluded all options of cancellation,

7 and the aforementioned object of sale left his possession and entered the proprietary control of the mentioned buyer, and the mentioned amount total from the contract of sale, the exclusion of fraud and the settlement price

8 of together 8o tümān-i tabrïzì in silver coinage which is equivalent to 1.6oo pieces of Dumişqālnìmī Nādirū rupees was completely and totally taken and acknowledged, and taken as sharia-conformant surety,

9 so that whenever a legal subterfuge should occur, he would be released from all obligations, and the legally correct formulary in Arabic and Persian during the recorded steps took place and became valid.

10 This took place on the date of 25 Jumādā II of the year 1156 .

Various seals and legal attestations:

a) I recognize what has been composed in it to the best of my knowledge, it has been written before me: "I entrust my affairs to God, his servant Muḥammad Ja 'far"

b) In the name of God the Merciful, the Beneficent, I [acknowledge] its contents [...], [seal]

c) It is as it is, and I am witness to it, it has been written by the minor servant, [seal]

d) The written content has been witnessed, the minor servant, [seal]

e) I acknowledge the support of God Almighty with all the joy of God, after the sharia-conform sale has become valid, it has been written before me, [seal]

f) Praise [...]

g) It has been witnessed what is in it, Muhammad Mahdī, [seal]

h) [...] Muḥammad Rashīd, [seal]

i) [seal $]$

j) 'Azīz Beg, brother of Muhamamad Taqīi, [seal] 


\section{Acknowledgements}

I am very grateful to the European Research Commission and the Lawforms project which provided funding for the research presented in this article. I also thank the European Research Commission and the Lawforms project for providing funds to publish this article, and the entire issue, in Open Access format.

\section{Bibliography}

'Āmilī, Bahā' al-Dīn Muhammad. 1388sh/2009. Jāmi'-i 'Abbāsīi: risāla-yi 'amalīya, bā hawāashīyi hasht faqūi 'ầlimaqām, Qum: Daftar-i intishārāt-i Islāmī.

Amin, Sayed Hassan. 1988a. Commercial Arbitration in Islamic and Iranian Law. Tehran/ Glasgow: Vahid (Tehran) and Royston (Glasgow).

Amin, Sayed Hassan. 1988b. Changes in the Law of Arbitration in Iran. Islamic and Comparative Law Quarterly 8/1: 35-47.

Beck, Sebastian. 1914. Neupersische Konversations-Grammatik mit besonderer Berücksichtigung der modernen Schriftsprache. Mit zahlreichen Schriftafeln und Texten in den wichtigsten Schriftarten, einer Lichtdrucktafel mit Münzen und Banknoten, einer Sammlung von Dokumenten und Briefen, darunter ein Ferman in Vierfarbendruck. Heidelberg: Julius Groos.

Beck, Sebastian. 1915. Schlüssel zur Neupersischen Konversations-Grammatik mit einer Einführung in den persischen Briefstil und in die selteneren persischen Schriftarten: Tälìq, Tulút und Šĕkästä-yĕ zĕnğ̀rr. Heidelberg: Julius Groos.

Bhalloo, Zahir. 2013. The Qajar Jurist and his Ruling: A Study of Judicial Practice in Nineteenth Century Iran. Unpublished Ph.D. Dissertation, Oxford, Wadham College. Bhalloo, Zahir. 2014. Judging the Judge: Judicial Competence in 19th Century Iran. Bulletin d'études orientales 63: 275-93.

Gilbar, Gad. 2008. The Rise and Fall of the Tujjār Councils of Representatives in Iran, 1884-85. Journal of the Economic and Social History of the Orient 51/4: 639-74.

Hamilton, Charles. 1870. The Hedaya: Commentary on the Islamic Laws, trans. by C. Hamilton. Reprint of the 2nd edition from 1870, New Delhi: Kitab Bhavan, 1994.

Hiillī al-Muhaqqiq al-Awwal, Ja far b. al-Ḥasan al-.1358sh/1997. Tarjuma-i färsī-i Sharāyic al-Islām, 2 vols., transl. Abū al-Qāsim b. Aḥmad Yazdī, ed. M. Taqī Dānish-Pazhūh. Tihrān: Intishārāt-i Danishgāh-i Tihrān.

Jahānpūr, Fāṭima. 1380sh/2001. Barrasī-yi chand ișțilāh dar muṣālaḥa-nāma-hā. Ganjīna-i Asnād 11/41-2: 79-83. 
Khumainī, Rūḥallāh. 1371sh/1992. Risāla-i taużịh al-masāil. 8th edition. Tihrān.

Kondo, Nobuaki. 2017. Islamic Law and Society in Iran: A Social History of Qajar Tehran. London: Routledge.

Lambton, Ann K.S. 1953. Landlord and Peasant in Persia: A Study of Land Tenure and Land Revenue Administration. London: Oxford University Press.

Lockhart, Laurence. 1938. Nadir Shah: A critical study based mainly upon contemporary sources. London: Luzac.

Mahdawī, Aṣghar and Īraj Afshār, ed. 138osh/2001. Yazd dar asnād-i Amīn al-Żarb (sālhā-yi 1288-1330 qamarī). Tihrān: Ṭalāya.

Mokri, M. 1963. Etude d'un titre de propriété du début du XVI ${ }^{\mathrm{e}}$ siècle provenant du Kurdistan. Journal Asiatique 251: 229-56.

Mūsawiyān, Sayyid 'Abbās; Dāwud Nașrābādī. 1388sh/20og. Țarāhīìi awrāq-i waqf bar mabnā-yi ‘aqd-i șulh wa waqf jihat-i ta’mīn-i mālīi țarḥ-hā-yi ‘āmm al-manfáa. Muțālacāt-i Iqtiṣād-i Islāmı̄ no. 3: 39-68.

Najafì (Șaḥib-i Jawāhir), Muḥammad Ḥasan b. Bāqir. 1274q/1858. Jawāhir al-Kalām fì sharh Sharāyic al-Islām. Volume 26: Kitāb al-ṣulh. Ișfahān: Dār Ihyā Turāth al-'Arabī, digital text edition based on the lithograph by Markaz al-Qāiimīya at www.ghae miyeh.com (accessed 01.09.2020).

Noth, Albrecht. 1973. Zum Verhältnis von kalifaler Zentralgewalt und Provinzen in umayyadischer Zeit: Die ,Șulh'-,'Anwa'-Traditionen für Ägypten und den Iraq. Die Welt des Islams 14: 150-62.

Othman, Aida. 2007. "And Amicable Settlement Is Best": Șulh and Dispute Resolution in Islamic Law. Arab Law Quarterly 21/1: 64-9o.

Owsia, Parviz. 1994. Formation of Contract: A Comparative Study under English, French, Islamic and Iranian Law. London: Graham \& Trotman.

Peirce, Leslie. 2003. Morality Tales: Law and Gender in the Ottoman Court of Aintab. Berkeley: University of California Press.

Rajabzade, Hashem and Koichi Haneda, ed. 1997. Fifty Five Persian Documents of Qajar Period: "Persian Documents" Series No. 1. Tokyo: IlCAA. (Studia Culturae Islamicae 59).

Rajabzadeh, Hashem, ed. 2019. Eighty-Eight Documents on Irrigation from Qajar Iran, with the cooperation of Kinji Eura and a preface by Kazuo Morimoto. Tokyo: Research and Information Center for Asian Studies/Institute for Advanced Studies on Asia, The University of Tokyo. ("Persian Documents" Series, 6).

Riżāầ, Umīd. 2008. Dar-āmadī bar asnād-i shar'īyi dawra-yi Qājār [Introduction to Shari'a Documents from Qajar Iran]. Tokyo: ILCAA. (Studia Culturae Islamicae, 92).

Santillana, David. 1925/1938. Istituzioni di diritto musulmano malichita: con riguardo anche al sistema sciafiita. 2 vols. Roma: Istituto per l'Oriente. 
Sartori, Paolo. 2011. The Evolution of Third-Party Mediation in Sharía Courts in 19thand early 2oth-century Central Asia. Journal of the Economic and Social History of the Orient 54/3: 311-52.

Sartori, Paolo. 2017. Visions of Justice: Sharîa and Cultural Change in Russian Central Asia. Leiden: Brill. (Handbuch der Orientalistik: Section 8 Uralic and Central Asian Studies, 24).

Schneider, Irene. 2002. Muḥammad Bāqir Šaftì (118o-126o/1766-1844) und die Isfahaner Gerichtsbarkeit. Der Islam 79/2: 240-73.

Shaftī, Muḥammad Bāqir al-. 1258q/1842. Kitāb-i su'āl va jawāab. Tihrān (lithograph).

Shīrāzī Hamzawī, 'Alī Muḥammad. 1327q/19o9. Sayyid al-inshā'-i naw-žuhūr. Bombay: Maṭbaci-i Fayż-rasān (lithograph).

Sutūda, Manūchihr, ed. 135osh/1971 to 1355sh/1976. Az Āstārā tā Istārbād. 8 vols. Tihrān: Intishārāt-i Anjuman-i Āsār-i Millī.

Tamdoğan, Işık. 2008. Sulh and the 18th Century Ottoman Courts of Üsküdar and Adana. Islamic Law and Society 15/1: 55-83.

Ṭūsī, Muḥammad b. al-Ḥasan 'Alī al-. 1349-51sh/1970-72. Al-Mabsūt fífiqh al-imāmìya, ed. M. Taqī al-Kashfī, 8 vols. Tihrān.

Werner, Christoph. 2000. What is a Mujtahid? Functions and Stratification of Tabrizi 'Ulama in the Early Qajar Period. Islamic Area Studies, Working Paper Series 19, Tokyo.

Werner, Christoph. 2003. Formal Aspects of Qajar Deeds of Sale. In Persian Documents, ed. Nobuaki Kondo. London: Routledge: 13-49.

Wichard, Johannes Christian. 1995. Zwischen Markt und Moschee. Wirtschaftliche Bedürfnisse und religiöse Anforderungen im frühen islamischen Vertragsrecht. Paderborn: Schöningh.

Women's Worlds in Qajar Iran, Harvard University Press, directed by Afsaneh Najmabadi, www.qajarwomen.org (accessed 01.02.2020). 